\title{
Response of tropical avifauna to visitor recreational disturbances: a case study from the Sinharaja World Heritage Forest, Sri Lanka
}

\author{
Nilusha S. Alwis ${ }^{1}$, Priyan Perera ${ }^{1 *}$ and Nihal P. Dayawansa ${ }^{2}$
}

\begin{abstract}
Background: We investigated the impact of human recreational disturbances on the distribution of birds along a popular nature trail in Sinhararja World Heritage Forest, Sri Lanka. It was hypothesized that visual and noise stimuli caused by the presence of humans affect the distribution of avifauna associated with this nature trail.

Methods: Nine circular plots of $25 \mathrm{~m}$ fixed-radius laid along the trail $(0 \mathrm{~m})$, and 18 plots laid perpendicular to the trail at 75 and $150 \mathrm{~m}$ intervals, were studied from March 2013 to January 2014. The degree of human recreational disturbances was assessed in terms of visitor group size (visual disturbance) and their noise level (sound disturbance). These disturbances were categorized along a four-point scale (no human disturbance, low, medium and high disturbance). The relationship between disturbance levels and the abundance of birds was statistically tested.

Results: ANOVA results revealed that the abundance of birds differed significantly under various intensities of recreational disturbances at each distance level. A significant negative correlation between abundance of birds and intensity of disturbance at $0 \mathrm{~m}$ distance suggests an avoidance of edge habitats by birds in the presence of humans. Abundance of birds increased at the 75 and $150 \mathrm{~m}$ distance levels with increasing disturbances occurring at the trail. Significant negative correlations were further observed between disturbance level and the abundance of birds in ground/understory and sub-canopy vertical strata of the forest at $0 \mathrm{~m}$ distance.

Conclusions: Under high levels of recreational disturbance occurring at this trail, the abundance of birds near the trail declined significantly, while bird abundance in the interior of the forest increased. The sensitivity of individual bird species to visitor disturbances varied with the vertical stratum of the forest they usually occupy. Birds occupying the ground, understory and sub-canopy are particularly sensitive to recreational disturbances while bird species occupying the canopy and above are less vulnerable to recreational disturbances.
\end{abstract}

Keywords: Recreational disturbances, Ecotourism, Tropical birds, Sinharaja World Heritage Forest, Habituation

\section{Background}

Nature-based tourism has wide implications for biodiversity-rich tropical countries. Recreational opportunities such as wildlife observation is an important dimension that is often considered in establishing protected areas (PAs), given that it is expected to generate public interest while ensuring the economic viability of their establishment (Suntikul et al. 2010). At present, Sri Lanka's PA

\footnotetext{
*Correspondence: priyan@sjp.ac.lk

1 Department of Forestry and Environmental Science, University of Sri Jayewardenepura, Nugegoda, Sri Lanka

Full list of author information is available at the end of the article
}

network, especially national parks and forest reserves, are increasingly becoming prime nature-based tourism destinations for both international and domestic tourists (Perera et al. 2012). Since visitor pressure continues to increase on PAs, their administrators are facing the quandary of positively meeting the diverse expectations of visitors while effectively conserving these biological resources.

It has been reported that increased non-consumptive uses of PAs, such as nature-based tourism, cause negative impacts on wildlife. Although the effect of recreational tourists is expected to be less than of logging or 
fragmentation (Chazdon et al. 2009; Borgmann 2010; Gibson et al. 2011), nevertheless visitors to wildlife refuges can disturb birds, causing them to leave their habitats temporarily or permanently. Recreational disturbances often cause birds to spend considerable amounts from their energy budget to avoid humans, i.e., the vital energy that otherwise could be conserved for survival, migration and breeding. Nature-based recreation can have significant negative effects at the individual, population and community level (Fernández-Juricic and Tellería 2000; Mallord et al. 2007; Steven et al. 2011; GonzálezOreja et al. 2012; Wang et al. 2013).

Much of the past work on impacts of recreational disturbances on avifauna has been focused on waterbirds, where the negative effects of human recreational activities on their foraging behavior and habitat use have been well documented (Fernández-Juricic and Tellería 2000; Verhulst et al. 2001; Rodgers and Schwikert 2002; Stolen 2003; Pease et al. 2005; Cardoni et al. 2008). Human recreational disturbances are also known to cause reduction of reproductive success and nesting failures (Bolduc and Guillemette 2003; Finney et al. 2005; McGowan and Simons 2006; Steven et al. 2011; Whitfield and Rae, 2014). As explained by Holm and Laursen (2009), disturbances caused by hikers alone can negatively affect territorial densities of certain birds, causing effective habitat loss for breeding. However, such impacts seem to be species-specific and for some birds, human use of recreational trails has no apparent effect on nest survival (Smith-Castro and Rodewald 2010).

Many studies have correlated higher pedestrian or vehicle traffic in wildlife refuges to reduced species richness and abundance of birds (Fernández-Juricic 2000; Bautista et al. 2004; Burger et al. 2004; Marcum 2005; Steven et al. 2011). However, not all bird species are equally affected by human recreational disturbances. Certain avian species can tolerate greater degrees of disturbances (Marcum 2005; Gill 2007; Cardoni et al. 2008). The response of birds to human recreational disturbances may depend on the nature or type of disturbance, as well as on the distance from the disturbance (FernándezJuricic et al. 2001a; Pease et al. 2005; Ruddock and Whitfield 2007). For instance, contrary to the general belief that motorized nature based tourism activities cause greater disturbances to birds (Stolen 2003; Schlacher et al. 2013), non-motorized recreation such as hiking and biking that often involve close encounters with birds have been found to cause more severe negative effects on a wide range of bird species (Buckley 2004; Pease et al. 2005). In the case of species that are sensitive to human recreational disturbances, continuous exposure to such disturbances may ultimately lead to permanent avoidance of habitats and changes in regular behavioral patterns (Fernández-Juricic 2000; Steven et al. 2011).

One of the key issues that need to be addressed in bird conservation in PAs, subject to human visitation, is whether these recreational disturbances would decrease the probability of habitat occupancy by birds and, if so, what species are likely to be most affected. As recreational activities in PAs are frequently cited as one of the principal issues of concern in biodiversity conservation, a proper understanding of the relationship between human recreational disturbances and their impacts on birds is essential for effective conservation and recreational planning in PAs, particularly those subject to high visitor pressure. Furthermore, such knowledge would be highly valuable in designing and planning sound visitor management strategies, setting appropriate visitor policies/ guidelines, as well as setting buffer zones to minimize potential recreational disturbances on birds (Rodgers and Schwikert 2002; Blumstein et al. 2003; Fernández-Juricic et al. 2004). Despite the importance of understanding possible impacts of human disturbances on avifauna, scientific evidence to assess the extent of this impact is limited in the literature, especially for birds in tropical regions (Steven et al. 2011). In order to bridge this information gap, this study investigated the effects of human recreational disturbances on the distribution and abundance of birds along a highly visited nature trail in a tropical lowland rainforest in Sri Lanka. How recreational disturbances occurring at this nature trail affect birds at different distances away from the trail and different vertical strata of the forest, were specifically examined.

\section{Methods}

Study site

This study was conducted in the northwestern part $\left(6^{\circ} 21^{\prime}-6^{\circ} 26^{\prime} \mathrm{N}, 80^{\circ} 06^{\prime}-80^{\circ} 11^{\prime} \mathrm{E}\right)$ of the Sinharaja Forest Reserve, a mid-elevation tropical lowland rainforest which has been designated as a UNESCO World Heritage Site, as well as a Man and Biosphere Reserve. The total extent of the Sinharaja Forest Reserve is 11187 ha, with an average annual rainfall varying between $3600 \mathrm{~mm}$ and $5000 \mathrm{~mm}$. The average monthly temperature varies between 22 and $28{ }^{\circ} \mathrm{C}$ (Gunatilleke and Gunatilleke 1981). The vegetation in general exhibits dense, tropical evergreen rain forest characteristics, dominated by Mesua and Shorea species in the canopy (Kotagama and Goodale 2004). The site is accessible via three main entrances with the entrance near the village of "Kudawa" being the mostly used entrance. The Sinharaja Forest Reserve is usually open to the public throughout the year, from 6:00 a.m. to 6:00 p.m. Monthly visitations to the forest vary from approximately 1000 to 5000 visitors, while 
annual visitations exceeded 31500 based on the visitor records for the period of 2012-2014 (Sri Lanka Forest Department 2014).

\section{Sampling}

Field work was carried out on a highly visited nature trail, i.e., the "Kudawa" nature trail that runs through the forest (Fig. 1). Data were collected during the period from March 2013 to January 2014. Total length of the selected segment of the nature trail was approximately $3.5 \mathrm{~km}$. We used $25 \mathrm{~m}$ fixed-radius circular plots to survey birds. Point counts of $25 \mathrm{~m}$ radius have been recommended for bird census in tropical forests where visibility is comparatively low (Sutherland 2006).

Nine point count stations were initially established along the trail to cover its study segment. Point count stations were demarcated at least $300 \mathrm{~m}$ apart on the nature trail. Two additional point count stations were established at 75 and $150 \mathrm{~m}$ inside the forest, perpendicular to each point count station on the trail. Accordingly, the entire study employed 27 fixed-radius point count stations. The vegetation structure and cover in many places near the nature trail differed noticeably when compared to the interior of the forest. This is mainly due to the presence of large canopy openings or gaps near the trail. Since this can affect the detectability of birds, such areas were avoided in siting point count stations and care was taken to select locations with similar habitat conditions (similar vegetation cover) as much as possible at each distance level.

Point counts were conducted between 8:00 a.m. and 6:00 p.m., mainly during weekends and holidays where higher visitor numbers were anticipated. During the study period, each point count station was visited at least on 10 occasions by the same field observer at various times of the day (by dividing the entire observation period into five equal time intervals of $2 \mathrm{~h}$ each) and in a different order to avoid visiting the same sampling point repeatedly at the same time. All birds seen or heard within a radius of $25 \mathrm{~m}$ from the center of the plot were recorded. When mixed-species foraging bird flocks were encountered, birds were counted in the opposite direction to their movement. Point counts were not conducted during days where heavy rain or strong winds were persistent. A total of 307 point counts were conducted at the 27 sampling stations during the 11-month study period.

\section{Measuring human recreational disturbances}

Visitors enter Sinharaja Forest Reserve for a variety of recreational purposes, such as bird-watching, nature photography, hiking, nature-based education and for picnics (Perera et al. 2012). The intensity and impact of disturbances caused by each type of recreational use differ widely. For the purpose of this study, recreational

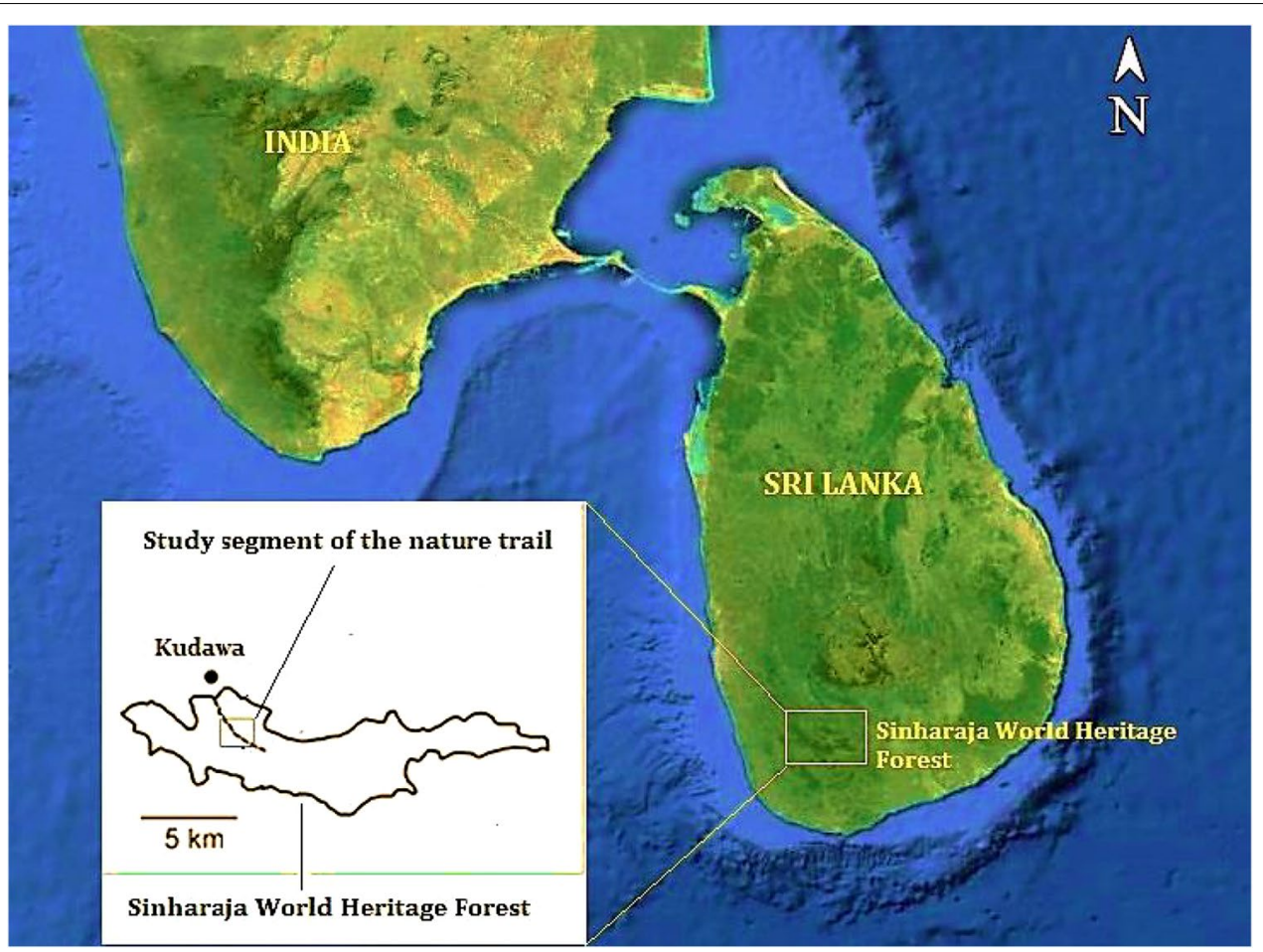

Fig. 1 Location of the study site 
disturbances were defined in terms of visual disturbances measured by group size, while noise disturbances were measured by the relative noise level of the visitor group. These simplified criteria were adopted to eliminate the complexity and number of variables that otherwise would have to be considered in relating recreational disturbances to the abundance of birds.

A pilot study was conducted to measure the sound levels occurring at the nature trail when visitor groups were present and absent. Sound levels were measured from a fixed point $10 \mathrm{~m}$ away from the edge of the trail using a digital sound level meter (Mastech ${ }^{\circledR}$ MS6700). Based on the sound levels recorded under different scenarios, an arbitrary scale consisting of four noise disturbance categories was developed: no human vocal disturbances ( $<35 \mathrm{~dB})$, low human vocal disturbances $(35-50 \mathrm{~dB})$, moderate human vocal disturbances $(50-65 \mathrm{~dB})$ and high human vocal disturbances $(>65 \mathrm{~dB})$. To eliminate any observer bias, a field assistant, who is well familiar with noise levels, was employed to record visitor data during the entire study period.

During the field sessions, all point count stations were visited by the first author while the field assistant was stationed on the nature trail to gather recreational disturbance data. For instance, when a bird census was being conducted on in a point count station located $75 \mathrm{~m}$ perpendicular to the trail inside the forest, the number of visitors passing both ways, was recorded at the corresponding point count station on the nature trail.

\section{Statistical analysis}

Since this study defined human recreational disturbances in terms of visual disturbances and noise disturbances, both the number of visitors and their relative noise level were used in deriving recreational disturbance profiles. Given that this involved variables measured in interval and ordinal scales respectively, the two-step cluster analysis in PASW@ v.18 was used to derive disturbance profiles statistically.

To examine the relationship between recreational disturbances and the presence of birds, data were sorted according to three distance levels $(0 \mathrm{~m}$ : nine plots on the trail; $75 \mathrm{~m}$ : nine plots located $75 \mathrm{~m}$ away from the trail; $150 \mathrm{~m}$ : nine plots located $150 \mathrm{~m}$ away from the trail). Point count stations established 75 and $150 \mathrm{~m}$ away from the trail were located in the forest interior. Hypothesis testing was performed using parametric statistical techniques in PASW@ v.18. The null hypothesis of "no significant differences between bird abundance under different recreational disturbance levels at a specific distance level" was statistically tested using one-way ANOVA.

It was also intended to test whether birds occupying different vertical strata of the forest have different responses to human recreational disturbances. Based on published literature (Henry 1998; Kotagama and Goodale 2004; Kotagama 2006; Harrison and Worfolk 2011; Warakagoda et al. 2012), all detected bird species were further grouped by the vertical strata they usually occupy viz. ground and understory $(<8 \mathrm{~m})$, sub-canopy $(8-25 \mathrm{~m})$, canopy $(25-35 \mathrm{~m})$ and above canopy $(>35 \mathrm{~m})$. A twoway ANOVA was employed to test statistically whether the bird abundance varies with the vertical forest strata under different recreational disturbance levels. Pearson's correlation tests were further used to examine the relationship between disturbance and abundance of birds in each stratum at each distance level.

Responses of different bird species to recreational disturbances were further examined using one-way ANOVA. For all the recorded bird species, data at individual species level were insufficient to proceed with subsequent statistical analysis to explore species level responses to recreational disturbances. Hence, the detection probability of greater than $20 \%$ for a species (calculated by dividing the number of point counts where the species was present by total point counts) was used as the screening criterion in order to investigate the species-level responses to recreational disturbances.

\section{Results}

Over the 11-month study period, a total of 5167 individual birds belonging to 45 species were encountered at the 27 sampling stations, of which 43 species were resident birds, including 19 endemic species and 2 migrant species (Appendix 1). The Orange-billed Babbler (Turdoides rufescens), the Ashy-headed Laughing-thrush (Garrulax cinereifrons), the Yellow-browed Bulbul (Pycnonotus luteolus) and the Dark-fronted Babbler (Rhopocichla atriceps) were among the most abundant species recorded. A total of 307 point counts were conducted at the 27 sampling stations and an average of $16.83(\mathrm{SE} \pm 1.17)$ number of birds were recorded during a point count with a range of $0-145$ birds. A total of 3267 visitors utilized the studied segment of this nature trail while the bird census was ongoing.

\section{Recreational disturbance profiles}

Four clusters were derived by the two-step clustering procedure, interpreted as recreational disturbance profiles/categories, referred to as "No Recreational Disturbance" (NRD), "Low Recreational Disturbance" (LRD), "Moderate Recreational Disturbance" (MRD) and "High Recreational Disturbance" (HRD). These four recreational disturbance categories were used as a key variable in subsequent statistical analyses and interpretation (Table 1). 
Table 1 Description of recreational disturbance profiles

\begin{tabular}{|c|c|c|c|c|}
\hline Cluster & 1 & 2 & 3 & 4 \\
\hline Name & $\begin{array}{l}\text { No recreational disturbance } \\
\text { (NRD) }\end{array}$ & $\begin{array}{l}\text { Low recreational disturbance } \\
\text { (LRD) }\end{array}$ & $\begin{array}{l}\text { Moderate recreational distur- } \\
\text { bance (MRD) }\end{array}$ & $\begin{array}{l}\text { High recreational disturbance } \\
(\mathrm{HRD})\end{array}$ \\
\hline Description & $\begin{array}{l}\text { No human vocal disturbances, } \\
\text { no visitors }\end{array}$ & $\begin{array}{l}\text { Silent to low human vocal } \\
\text { disturbances, average number } \\
\text { of visitors }=4\end{array}$ & $\begin{array}{l}\text { Moderate human vocal distur- } \\
\text { bances, average number of } \\
\text { visitors }=17\end{array}$ & $\begin{array}{l}\text { High human vocal disturbances, } \\
\text { average number of visi- } \\
\text { tors }=40\end{array}$ \\
\hline Cluster size & $\begin{array}{l}51.79 \% \\
(n=159)\end{array}$ & $\begin{array}{l}26.38 \% \\
(n=81)\end{array}$ & $\begin{array}{l}14.33 \% \\
(n=44)\end{array}$ & $\begin{array}{l}7.50 \% \\
(n=23)\end{array}$ \\
\hline
\end{tabular}

\section{Association between disturbance categories and abundance of birds}

In general, birds were more abundant in habitat edges near this nature trail (Fig. 2). To test whether the abundance of birds would statistically vary under different intensities of recreational disturbances at each distance level, one-way ANOVA tests were employed. The abundance of birds varied significantly under different intensities of recreational disturbances at each distance level at $p<0.05$. Post-hoc comparisons further suggest that the abundance of birds under less recreational disturbances (NRD and LRD) is significantly higher than bird abundance under greater levels of disturbances (MRD and HRD) at the $0 \mathrm{~m}$ distance level (Table 2).

Pearson's correlation tests revealed different types of significant relationships between abundance of birds and disturbance categories at each distance level. A significant negative correlation was observed between the abundance of birds and disturbance category at $0 \mathrm{~m}$ distance, while significant positive correlations between the same variables were evident in point count stations located 75 and $150 \mathrm{~m}$ away from the trail (Table 2). Thus, the abundance of birds decreased with human disturbance at $0 \mathrm{~m}$

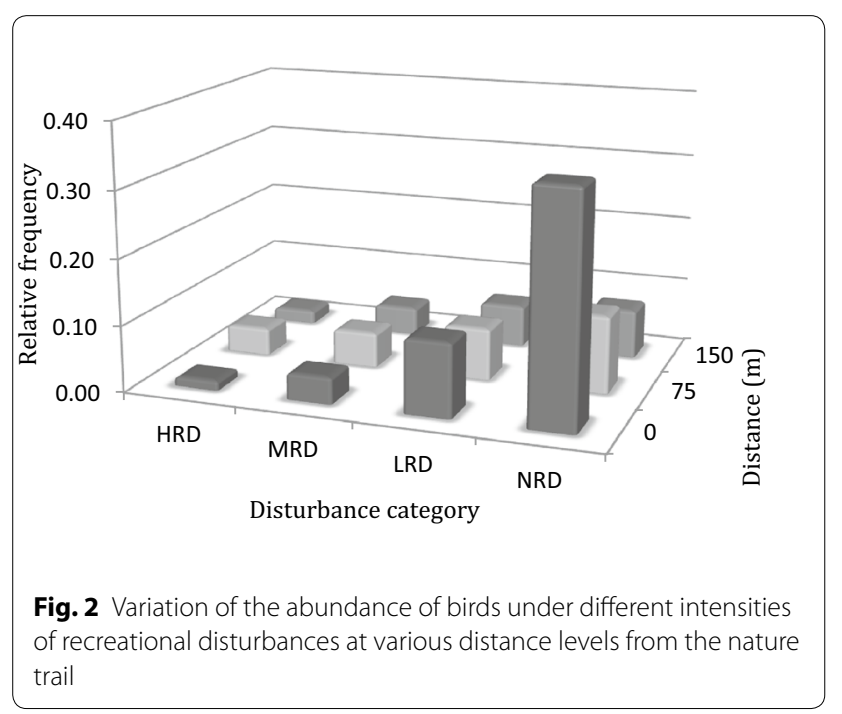

distance, while bird abundance increased at 75 and $150 \mathrm{~m}$ distance levels with increasing human disturbances occurring at the trail.

The two-way ANOVA revealed no statistically significant interaction between the effects of disturbance level and vertical strata on bird abundance at $0 \mathrm{~m}$ distance $(F=0.905, p=0.521)$. Bird abundance differed significantly with disturbance $(F=4.617, p<0.001)$, but not with vertical strata of the forest $(F=0.245, p=0.865)$. Statistically non-significant results for the effects of disturbance level and vertical strata on bird abundance were further evident at the 75 and $150 \mathrm{~m}$ distance levels.

Significant negative Pearson's correlations were observed between disturbance level and abundance of birds occupying the ground and understory $(r=-0.230$, $p<0.001)$ and the sub-canopy $(r=-0.212, p<0.001)$ vertical strata of the forest at $0 \mathrm{~m}$ distance. At 75 and $150 \mathrm{~m}$ distances away from the nature trail, the correlation between the two variables was insignificant except in the sub-canopy at the $75 \mathrm{~m}$ distance level (Table 3). Hence, the abundance of birds occupying ground and understory, as well as the sub-canopy layers at $0 \mathrm{~m}$ distance decreased with human disturbances, while bird abundance increased in the sub-canopy layer at the $75 \mathrm{~m}$ distance level with increasing disturbances at the nature trail.

Response of avifaunal species to recreational disturbances Of the 45 bird species recorded during our field surveys, sufficient data were available for only 19 species to proceed with subsequent statistical analyses to explore species level responses to recreational disturbances. Accordingly, analysis of species-level responses was restricted to those 19 bird species. Given that no recreational disturbances occurred at the trail, the mean number of birds recorded at point counts along the trail $(0 \mathrm{~m}$ level) was significantly higher $(p<0.05)$ for the following species: Ashy-headed Laughing-thrush, Brown-breasted Flycatcher (Muscicapa muttui), Greater Flameback (Chrysocolaptes lucidus), Dark-fronted Babbler, Malabar Trogon (Harpactes fasciatus), Orange-billed Babbler, Spot-winged Thrush (Zoothera spiloptera), Sri Lanka Scimitar Babbler (Pomatorhinus melanurus) and 
Table 2 One-way ANOVA for the dependence of bird abundance on the intensity of recreational disturbances at different distances from the trail

\begin{tabular}{|c|c|c|c|c|c|c|c|c|}
\hline \multirow[t]{2}{*}{ Distance from trail (m) } & \multicolumn{4}{|c|}{ Mean number of birds } & \multicolumn{2}{|c|}{ One-way ANOVA } & \multicolumn{2}{|c|}{ Pearson's correlation } \\
\hline & NRD & LRD & MRD & HRD & $F$ & $p$ & $r$ & $p$ \\
\hline 0 & $1.53^{\mathrm{a}}$ & $1.17^{\mathrm{a}}$ & $0.70^{b}$ & $0.28^{\mathrm{b}}$ & 12.255 & $0.001^{*}$ & -0.134 & $0.001^{*}$ \\
\hline 75 & $0.54^{\mathrm{a}}$ & 0.81 & 0.80 & $0.92^{\mathrm{b}}$ & 3.066 & $0.027^{*}$ & 0.064 & $0.006^{*}$ \\
\hline 150 & $0.36^{\mathrm{a}}$ & $0.53^{b}$ & $0.67^{b}$ & $0.75^{b}$ & 6.848 & $0.001^{*}$ & 0.104 & $0.001^{*}$ \\
\hline
\end{tabular}

Items with different superscripts (lowercase letters) indicate significant difference of means according to Games-Howell post hoc tests. Items without superscripts do not significantly differ from ones with superscripts

* Statistical significance at $a=0.05$ level

Yellow-browed Bulbul (Appendix 2). These species in general seem to prefer relatively open habitats near jungle trails inside the forest as their foraging cover.

Of the 19 species with sufficient data, 11 species showed statistically significant differences in abundance $(p<0.05)$ under various intensities of recreational disturbances for at least one of the three distance levels considered (Appendix 2). According to post hoc comparisons, abundance of Brown-headed Barbet (Megalaima zeylanica), Layard's Parakeet (Psittacula calthropae), Red-faced Malkoha (Phaenicophaeus pyrrhocephalus), Scarlet Minivet (Pericrocotus flammeus), Sri Lanka Crested Drongo (Dicrurus lophorhinus), Sri Lanka Junglefowl (Gallus lafayetii), Sri Lanka Myna (Gracula ptilogenys) and Tickell's Blue Flycatcher (Cyornis tickelliae) were found to be independent from the intensity of recreational disturbances at all three distance levels considered.

The abundance of Ashy-headed Laughing-thrush, Brown-breasted Flycatcher, Greater Flameback, Darkfronted Babbler, Malabar Trogon, Orange-billed Babbler,
Red-faced Malkoha, Scarlet Minivet, Spot-Winged Thrush, Sri Lanka Scimitar Babbler (Pomatorhinus melanurus), Tickell's Blue Flycatcher and Yellow-browed Bulbul in sampling plots along the trail was negatively correlated $(p<0.05)$ with the intensity of recreational disturbances (Appendix 2). These species seem to be sensitive to recreational disturbances and as the intensity of recreational disturbances increases at the nature trail, their presence near the trail declined significantly. Interestingly, the mean number of Sri Lanka Blue Magpies (Urocissa ornate) recorded under low and moderate levels of recreational disturbances were significantly higher, indicating their higher tolerance to human presence.

The abundance of Black-naped Monarch (Hypothymis azurea), Dark-fronted Babbler (Rhopocichla atriceps), Malabar Trogon and Sri Lanka Scimitar Babbler were positively correlated with the intensity of recreational disturbances at the more interior parts of the forest $(75 \mathrm{~m}$ distance level). This suggests a possible avoidance of habitat edges by these species, flushing deeper into the forest

Table 3 Mean number of birds and Pearson's correlations between disturbance and abundance of birds in different vertical strata of the forest

\begin{tabular}{|c|c|c|c|c|c|c|c|}
\hline \multirow[t]{2}{*}{ Distance from trail (m) } & \multirow[t]{2}{*}{ Strata } & \multicolumn{4}{|c|}{ Mean number of birds } & \multicolumn{2}{|c|}{ Pearson's correlation } \\
\hline & & NRD & LRD & MRD & HRD & $r$ & $p$ \\
\hline \multirow[t]{4}{*}{0} & Ground and understory & 2.77 & 2.20 & 1.23 & 0.16 & -0.230 & $0.001^{*}$ \\
\hline & Sub-canopy & 2.92 & 2.28 & 0.97 & 0.41 & -0.212 & $0.001^{*}$ \\
\hline & Canopy & 1.58 & 1.88 & 1.22 & 1.13 & -0.116 & 0.141 \\
\hline & Above-canopy & 1.41 & 1.54 & 0.80 & 1.10 & -0.150 & 0.233 \\
\hline \multirow[t]{4}{*}{75} & Ground and understory & 1.52 & 1.25 & 1.00 & 3.00 & 0.202 & 0.218 \\
\hline & Sub-canopy & 1.86 & 1.76 & 1.83 & 3.83 & 0.263 & $0.019^{*}$ \\
\hline & Canopy & 4.60 & 1.50 & 3.50 & 1.99 & -0.289 & 0.451 \\
\hline & Above-canopy & 2.00 & 2.67 & 3.00 & 2.00 & 0.186 & 0.474 \\
\hline \multirow[t]{4}{*}{150} & Ground and understory & 3.29 & 4.33 & 4.83 & 3.50 & 0.087 & 0.492 \\
\hline & Sub-canopy & 3.29 & 4.22 & 4.05 & 1.36 & 0.004 & 0.958 \\
\hline & Canopy & 2.33 & 2.94 & 1.67 & 1.00 & -0.062 & 0.733 \\
\hline & Above-canopy & 1.64 & 2.22 & 0.67 & 1.50 & -0.114 & 0.563 \\
\hline
\end{tabular}

* Statistical significance at $a=0.05$ level 
under increasing intensities of recreational disturbance occurring at the trail. Results of one-way ANOVA tests further support this observation (Appendix 2).

\section{Discussion}

The impact of human presence and disturbances on birds has been well documented in the literature. As interpreted by Fernández-Juricic et al. (2001a), birds in general perceive human presence as a predation risk and tend to flee or show avoidance behavior. In the context of nature-based tourism, earlier studies have reported low abundance and species richness of birds under higher pedestrian or vehicle traffic in wildlife refuges (Klein et al. 1995; Fernández-Juricic 2000; Bautista et al. 2004; Burger et al. 2004; Marcum 2005). However, these relationships have been observed for avifauna in temperate regions and mostly for aquatic birds (Steven et al. 2011). Focusing on the avifaunal community in this tropical lowland rainforest in Sri Lanka, findings of this study further support the negative relationships found between the abundance of birds and increasing human recreational disturbances, elaborated by previous research.

Our results further suggest that not all tropical bird species are equally affected by human recreational disturbances. As in the case of temperate birds (Marcum 2005; Gill 2007), certain tropical bird species are capable of tolerating greater degrees of human recreational disturbances. The sensitivity of individual bird species to visitor recreational disturbances seems to vary with the stratum/ layer of the rain forest usually occupied by bird species. Ashy-headed Laughing-thrush, Dark-fronted Babbler, Spot-winged Thrush and Tickell's Blue Flycatcher, found to be particularly sensitive to recreational disturbances, are all forest birds that usually occupy the understory and edges of jungle trails (Kotagama and Goodale 2004; Goodale and Kotagama 2005; Harrison and Worfolk 2011; Warakagoda et al. 2012). As the intensity of human recreational disturbances increased, their presence near the trail declined significantly. This suggests that birds generally occupying the ground and understory are likely to be more affected by visitors. The response of birds to human recreational disturbances can vary by the distance to the disturbances (Fernández-Juricic et al. 2001a, b; Borgmann 2010). In the studied segment of our nature trail, only hiking is allowed and the distance between recreationalists using the nature trail and birds occupying the lower strata of the forest is smaller. Past studies have also shown that forms of recreation, such as hiking, can cause significant negative effects on a wide range of bird species (Buckley 2004; Pease et al. 2005).

Black-naped Monarch, Brown-breasted Flycatcher, Brown-headed Barbet, Greater Flameback, Malabar Trogon, Orange-billed Babbler, Sri Lanka Blue Magpie, Sri
Lanka Scimitar Babbler and Yellow-browed Bulbul commonly occupy the sub-canopy layer of the forest. Out of nine sub-canopy occupying bird species, Black-naped Monarch, Brown-headed Barbet and Sri Lanka Blue Magpie showed higher tolerance to visitor recreational disturbances. The Brown-headed Barbet is not exclusively a forest bird and a common resident in a variety of habitats, including landscapes modified anthropologically (Harrison and Worfolk 2011). Their greater adaptability to modified habitats may explain why this species is not substantially avoiding edges of our trail under higher intensities of recreational disturbances. Although a forest bird, the Sri Lanka Blue Magpie did not show noticeable signs of avoidance behavior under human presence. Instead, they seem to be attracted towards small to medium sized visitor groups. This was evident by the high number of Sri Lanka Blue Magpies being recorded under low and moderate levels of recreational disturbances and their numbers showing a positive correlation with disturbance level, although the relationship was not statistically significant. This suggests a possible habituation of the Sri Lanka Blue Magpie population ranging around the Kudawa nature trail to low and moderate levels of recreational disturbances or human presence. In fact, during our field studies, it was often observed that a group of Sri Lanka Blue Magpies perching near the trail in anticipation of food, when visitor groups were present. Similar behavioral observations were made on ground occupying Sri Lanka Junglefowl. Visitors feeding blue magpies and junglefowls were a common observation during field studies. Such visitor behavior along with exposure to recurring recreational disturbances can alter the normal behavior of birds and induce habituation to human presence (Marcum 2005; Peters and Otis 2006; Baudains and Lloyd 2007; Smith-Castro and Rodewald 2010).

In general, recreational disturbances had less effect on birds occupying canopy and emergent layers. Layard's Parakeet and Sri Lanka Crested Drongo commonly occupy the canopy or the upper parts of the sub-canopy (Kotagama and Goodale 2004; Goodale and Kotagama 2005; Harrison and Worfolk 2011; Warakagoda et al. 2012). As indicated by the results of our ANOVAs in Appendix 2, their abundance was found to be independent from the intensity of recreational disturbances at various distances from the trail. Among the bird species occupying the emergent layer of the forest, the Sri Lanka Myna-the only species with sufficient data for analysis in this study, also showed no statistically significant variation in its abundance under different intensities of recreational disturbances at various distances from the trail. Since these species commonly forage and occupy the canopy above $25 \mathrm{~m}$ from the ground, they may be less 
inclined to perceive human presence as a predation risk (Fernández-Juricic et al. 2001b) and thus less concerned about leaving the edges of this nature trail. However, despite being canopy occupants, the abundance of the Red-faced Malkoha and Scarlet Minivet was negatively correlated with the intensity of recreational disturbances at the trail, indicating their comparatively smaller tolerance to human presence.

The abundance of Ashy-headed Laughing-thrush, Brown-breasted Flycatcher, Greater Flameback, Darkfronted Babbler, Malabar Trogon, Orange-billed Babbler, Spot-Winged Thrush, Sri Lanka Scimitar Babbler and Yellow-browed Bulbul was higher along the jungle trail when no humans were present. These species generally prefer relatively open spaces inside the forest (Harrison and Worfolk 2011; Warakagoda et al. 2012). Under moderate and high recreational disturbances, the abundance of these species increased at the $75 \mathrm{~m}$ distance level from the trail. These fluctuations in abundance provide possible evidence for differing fleeing distances of bird species. The Ashy-headed Laughing-thrush, Dark-fronted Babbler, Orange-billed Babbler and Sri Lanka Scimitar Babbler are characteristically weak flyers (Siriwardhane 2007; Harrison and Worfolk 2011; Warakagoda et al, 2012) and do not flush far from the jungle trail. A statistically significant dependence of abundance on the intensity of recreational disturbances was observed for Malabar Trogons, indicating that they flush beyond $50 \mathrm{~m}$ under increasing visitor disturbances. However, other species such as the Brown-breasted Flycatcher, Greater Flameback and Yellow-browed Bulbul with good flight abilities did not seem to flush beyond $50 \mathrm{~m}$ from the trail. Hence there is only weak evidence to support the hypothesis that strong flyers flush deeper into the forest.

Territory size and territoriality may be important factors that determine how far birds would move away from a disturbance. Species, defending territories, are more likely to have reduced flight initiation distances and are less likely to move out of their territories under disturbances, although such responses are not always universal (Stankowich and Blumstein 2005). The Spot-winged Thrush is a highly territorial bird that seldom abandons its territory under disturbances (Weerakoon 2007). Instead, such species rely on camouflage in the vegetation. The abundance of Tickell's Blue Flycatcher also did not increase substantially under disturbances in the inner parts of the forest, indicating its territorial behavior (Rasmussen and Anderton 2012).

Another possible factor that can affect the response of different bird species to recreational disturbance in this forest is the predominance of mixed-species bird flocks. Many bird species recorded in this study, such as Orange-billed Babbler, Ashy-headed Laughing-thrush, Dark-fronted Babbler, Malabar Trogon, Red-faced Malkoha, Scarlet Minivet, and Yellow-browed Bulbul are known to participate quite regularly in mixed-species bird flocks (Kotagama and Goodale 2004; Goodale and Kotagama 2005). It was observed that the abundance of these species including the Orange-billed Babbler, the nuclear species of the flock system, were negatively correlated with increasing intensities of recreational disturbances. As such, mixed-species bird flocks may be negatively affected by visitor groups and under such circumstances, a flock can avoid habitat edges and travel quite quickly to the interior of the forest. The increase in abundance of the Malabar Trogon and Black-naped Monarch at $75 \mathrm{~m}$ level with the intensity of recreational disturbances may be explained by this phenomenon. Although a bird with a small territory, the abundance of the Dark-fronted Babbler was positively correlated with intensity of recreational disturbance at the $75 \mathrm{~m}$ distance level. They are known to join mixed-species foraging bird flocks usually within their territory (Shermila and Wikramasinghe 2013). Moreover, other research suggest that flush distances of certain bird species can be further associated with habitat structure represented by features such as vegetation cover, shrub and tree height (Fernández-Juricic et al. 2001b).

Some limitations of the study should be acknowledged. First, the structure of the forest near this nature trail is somewhat open and disturbed and differs from the forest interior. As such, the ability to detect birds is comparatively higher near the trail than inside the forest. Although efforts were made during the study design to avoid significantly open areas near the trail, higher abundance of birds near the trail may still be affected by greater visibility. All the same, there were several edgespecialists among the bird species recorded. It is well documented that mixed-species bird flocks of the Sinharaja forest tend to use habitat edges such as cut-over areas near the trails quite heavily (Kotagama and Goodale 2004; Goodale and Kotagama 2005). Secondly, the bird activity is relatively high in the early morning, apparently a time of low visitor activity. In general, larger visitor groups were more frequent after 10:00 a.m. while smaller visitor groups including birdwatchers entered the reserve during the early hours of the day, i.e., between 6:00 and 8:00 a.m. The study design accounted for this factor by avoiding bird census for this period, yet the effect of this compounding variable on bird abundance cannot be completely ignored.

Also, it is worth studying the movements of individually marked birds to determine their actual distance of 
displacement, minimum approaching distance, habitats where they seek refuge when disturbed and how they habituate due to their regular contact with visitors. Such information will be vital in recreational planning and management to minimize the disturbances to avifauna.

\section{Implications for management}

Recent visitor studies conducted at the Sinharaja World Heritage Forest have revealed that most visitors to this forest are "picnickers", defined as the visitors who are visiting the destination with the primary motive of spending free time with family/friends with nature observation/ appreciation a secondary motive (Perera et al. 2012). Such visitors often show a type of behavior that is potentially disturbing to wildlife. If human recreational activities in a forest reserve are displacing birds from their preferred habitats, the primary conservation objectives of the forest reserve are not met.

Findings of this research stress the importance of introducing sound visitor management strategies. Many birds can tolerate low intensity recreational disturbances, i.e., disturbances due to the presence of smaller and less noisy visitor groups (Remacha et al. 2011). Hence, visitor management strategies should be ideally focused on limiting the group size while encouraging appropriate visitor behavior. Strengthening park services such as nature interpretation, visitor education and awareness play a key role in this regard. Only small visitor groups should be allowed to more sensitive areas of the forest. Jungle trails that run through sensitive areas/habitats of the forest should be allowed for low intensity recreational uses under close supervision of management.

Owing to the inherent nature of the study design, the findings of this study may have local applicability. Similar studies should be repeated in other tropical forest settings elsewhere to improve our understanding of how avian communities respond to various levels of recreational disturbances. Furthermore, the methodology used in this study to develop recreational disturbance profiles is based on relative noise levels (a crude measures of noise) and group size. Possible visual disturbances for birds due to the color of clothes that visitors are wearing were not considered. Simulations studies could be done to understand such scenarios better. Nonetheless, reserve managers can directly incorporate the findings of this study into adaptive management cycles based on visual observations of the distribution of bird assemblages and recreational uses of nature trails in tropical lowland forest settings without engaging in time-consuming and expensive site-specific studies.

\section{Conclusion}

Heavy use of nature trails for recreational purposes has affected the bird species that occur on the well-known Kudawa nature trail in the Sinharaja World Heritage Forest. Under high levels of disturbance, bird communities avoided edge habitats and flushed far into the forest (up to $150 \mathrm{~m}$ ). Certain avian species seem to tolerate greater degrees of recreational disturbances. The sensitivity of individual bird species to visitor recreational disturbances vary with the stratum/layer of the rain forest usually occupied by these bird species. Effects of recreational disturbances were more profoundly felt by birds occupying understory and sub-canopy layers of the forest near the nature trail. Accordingly, the following species, i.e., Ashy-headed Laughing-thrush, Dark-fronted Babbler, Spot-Winged Thrush, Tickell's Blue Flycatcher, Brownbreasted Flycatcher, Greater Flameback, Malabar Trogon, Orange-billed Babbler, Sri Lanka Scimitar Babbler and Yellow-browed Bulbul avoid habitat edges along the jungle trail under increased visitor activity. Bird species occupying the canopy and higher layers of the forest were more tolerant to recreational disturbances.

\section{Authors' contributions \\ NA contributed through data collection, analysis and manuscript compiling. PP was responsible for overall supervision of the research including the plan- ning, execution, data analysis and writing of the manuscript. ND contributed in planning and execution of the research, manuscript reviewing and editing. All authors read and approved the final manuscript. \\ Author details \\ 1 Department of Forestry and Environmental Science, University of Sri Jayewardenepura, Nugegoda, Sri Lanka. ${ }^{2}$ Department of Zoology, University of Colombo, Colombo, Sri Lanka.}

\section{Acknowledgements}

The authors wish to acknowledge the Sri Lanka Forest Department for granting permission to conduct this study at the Sinharaja World Heritage Forest and the anonymous reviewers for their constructive comments which improved the manuscript substantially.

\section{Competing interests}

The authors declare that they have no competing interests.

\section{Appendix 1}

See Table 4. 
Table 4 List of species encountered and their relative abundance. Source: BirdLife International (2015)

\begin{tabular}{|c|c|c|c|c|c|c|}
\hline Family & Scientific name & Common name & Stratum & Relative abundance (\%) & TS & GCS \\
\hline Accipitridae & Accipiter virgatus (Temminck, 1822) & Besra & - & 0.06 & $\mathrm{BrR}$ & LC \\
\hline Aegithinidae & Aegithina tiphia (Linnaeus, 1758) & Common lora & S & 0.06 & $\mathrm{BrR}$ & LC \\
\hline Bucerotidae & Ocyceros gingalensis (Shaw, 1811) & Sri Lanka Grey Hornbill & C & 0.13 & E & LC \\
\hline Campephagidae & Pericrocotus flammeus (Forster, 1781) & Scarlet Minivet & C & 4.36 & $\mathrm{BrR}$ & LC \\
\hline Chloropseidae & Chloropsis aurifrons (Temminck, 1829) & Golden-fronted Leafbird & C & 0.34 & $\mathrm{BrR}$ & LC \\
\hline Columbidae & Chalcophops indica (Linnaeus, 1758) & Emerald Dove & $U$ & 0.09 & $\mathrm{BrR}$ & LC \\
\hline Columbidae & Ducula aenea (Linnaeus,1766) & Green Imperial-Pigeon & $C$ & 0.11 & $\mathrm{BrR}$ & LC \\
\hline Columbidae & Treron pompadora (Gmelin, 1789) & Sri Lanka Green Pigeon & A & 0.18 & E & VU \\
\hline Corvidae & Urocissa ornate (Wagler, 1829) & Sri Lanka Blue Magpie & S & 2.61 & E & VU \\
\hline Cuculidae & Centropus chlororhynchus (Blyth, 1849) & Sri Lanka Green-billed Coucal & $U$ & 0.06 & E & $\mathrm{VU}$ \\
\hline Cuculidae & $\begin{array}{l}\text { Phaenicophaeus pyrrhocephalus (Pen- } \\
\text { nant, 1769) }\end{array}$ & Sri Lanka Red-faced Malkoha & $C$ & 1.86 & $\mathrm{E}$ & $\mathrm{VU}$ \\
\hline Dicaeidae & Dicaeum erythrorynchos (Latham, 1790) & Pale-billed Flower-pecker & S & 0.08 & $\mathrm{BrR}$ & LC \\
\hline Dicaeidae & Dicaeum vincens (Sclater,1872) & Sri Lanka White-throated Flowerpecker & S & 0.17 & E & NT \\
\hline Dicruridae & Dicrurus lophorhinus (Vieillot, 1817) & Sri Lanka Crested Drongo & S & 2.63 & E & - \\
\hline Dicruridae & Dicrurus caerulescens (Linnaeus, 1758) & White-bellied Drongo & S & 0.08 & $\mathrm{BrR}$ & LC \\
\hline Hirundinidae & Hirundo hyperythra (Blyth, 1849) & Sri Lanka Swallow & - & 0.11 & PE & - \\
\hline Monarchiidae & Hypothymis azurea (Boddaert, 1783) & Black-naped Monarch & S & 1.97 & $\mathrm{BrR}$ & LC \\
\hline Muscicapidae & Cyornis tickelliae (Blyth, 1843) & Tickell's Blue Flycatcher & $U$ & 3.02 & $\mathrm{BrR}$ & LC \\
\hline Muscicapidae & Muscicapa muttui (Layard, 1854) & Brown-breasted Flycatcher & S & 1.80 & M & LC \\
\hline Nectariniidae & Nectarinia zeylonica (Linnaeus, 1766) & Purple-rumped Sunbird & S & 0.36 & $\mathrm{BrR}$ & LC \\
\hline Paridae & Pavus major (Linnaeus, 1758) & Great tit & C & 0.09 & $\mathrm{BrR}$ & LC \\
\hline Phasianidae & Galloperdix bicalcarata (Forster, 1781) & Sri Lanka Spurfowl & $U$ & 0.36 & E & LC \\
\hline Phasianidae & Gallus lafayetii (Lesson, 1831) & Sri Lanka Junglefowl & $U$ & 2.57 & $E$ & LC \\
\hline Picidae & Chrysocolaptes lucidus (Scopoli, 1786) & Greater Flameback & $S$ & 2.42 & PE & LC \\
\hline Picidae & Picus chlorolophus (Vieillot,1818) & Lesser Yellow-nape & S & 0.17 & $\mathrm{BrR}$ & LC \\
\hline Psittacidae & Loriculus beryllinus (Forster, 1781) & Sri Lanka Hanging Parrot & C & 0.09 & E & LC \\
\hline Psittacidae & Psittacula calthropae (Blyth,1849) & Layard's Parakeet & C & 2.80 & $E$ & LC \\
\hline Pycnonotidae & Hypsipetes leucocephalus (Gmelin, 1789) & Black Bulbul & A & 0.75 & $\mathrm{BrR}$ & LC \\
\hline Pycnonotidae & Iole indica (Jerdon, 1839) & Yellow-browed Bulbul & S & 7.53 & $\mathrm{BrR}$ & LC \\
\hline Pycnonotidae & Pycnonotus luteolus (Lesson,1841) & White-browed Bulbul & S & 4.30 & $\mathrm{BrR}$ & LC \\
\hline Pycnonotidae & Pycnonotus melanicterus (Gmelin, 1789) & Black-capped Bulbul & S & 0.26 & PE & LC \\
\hline Ramphastidae & Megalaima flavifrons (Cuvier, 1816) & Yellow-fronted Barbet & S & 0.32 & $E$ & LC \\
\hline Ramphastidae & Megalaima rubricapillus (Gmelin, 1788) & Crimson-fronted Barbet & S & 0.04 & PE & LC \\
\hline Ramphastidae & Megalaima zeylanica (Gmelin,1788) & Brown-headed Barbet & S & 2.72 & $\mathrm{BrR}$ & LC \\
\hline Sittidae & Sitta frontalis (Swainson, 1820) & Velvet-fronted Nuthatch & S & 0.56 & $\mathrm{BrR}$ & LC \\
\hline Sturnidae & Gracula ptilogenys (Blyth, 1846) & Sri Lanka Myna & A & 2.53 & E & NT \\
\hline Sturnidae & Sturnus albofrontatus (Layard, 1854) & Sri Lanka White-faced Starling & A & 0.69 & $E$ & $\mathrm{VU}$ \\
\hline Sylviidae & Phylloscopus trochiloides (Sundevall, 1837) & Green Warbler & $U$ & 0.08 & M & LC \\
\hline Timaliidae & Garrulax cinereifrons (Blyth,1851) & Ashy-headed Laughing-thrush & $U$ & 14.06 & E & $\mathrm{VU}$ \\
\hline Timaliidae & Pomatorhinus melanurus (Blyth, 1847) & Sri Lanka Scimitar Babbler & S & 4.30 & E & LC \\
\hline Timaliidae & Rhopocichla atriceps (Jerdon,1839) & Dark-fronted Babbler & $U$ & 5.58 & $\mathrm{BrR}$ & LC \\
\hline Timaliidae & Turdoides rufescens (Blyth,1847) & Orange-billed Babbler & $S$ & 21.84 & E & NT \\
\hline Turdidae & Zoothera spiloptera (Blyth, 1847) & Spot-Winged Thrush & $U$ & 3.08 & E & NT \\
\hline Upopidae & Harpactes fasciatus (Pennant1769) & MalabarTrogon & C & 2.63 & $\mathrm{BrR}$ & LC \\
\hline Zosteropidae & Zosterops ceylonensis (Holdsworth, 1872) & Sri Lanka White-eye & $S$ & 0.15 & $\mathrm{E}$ & LC \\
\hline
\end{tabular}

Relative abundance computed by dividing the number of individuals from each species recorded during the study period by the total number of birds recorded during the study period

$T S$ taxonomic status, E endemic, BrR breading resident, M migrant, GCS global conservation status, $V U$ vulnerable, NT near threatened, $L C$ least concerned. Strata: $U$ ground and understory, $S$ sub-canopy, C canopy, A above-canopy 


\section{Appendix 2}

See Table 5.

Table 5 One-way ANOVAs for the dependence of individual species abundance on the intensity of recreational disturbances at three distances from the trail

\begin{tabular}{|c|c|c|c|c|c|c|c|c|c|}
\hline \multirow[t]{2}{*}{ Species } & \multirow[t]{2}{*}{$\begin{array}{l}\text { Distance from } \\
\text { trail (m) }\end{array}$} & \multicolumn{4}{|c|}{ Mean number of birds } & \multicolumn{2}{|c|}{ One-way ANOVA } & \multicolumn{2}{|c|}{$\begin{array}{l}\text { Pearson's correla- } \\
\text { tion }\end{array}$} \\
\hline & & NRD & LRD & MRD & HRD & $F$ & $p$ & $r$ & $p$ \\
\hline Ashy-headed Laughing-thrush & 0 & $4.63^{\mathrm{a}}$ & $1.37^{\mathrm{b}}$ & $0.08^{c}$ & $0.00^{c}$ & 3.330 & $0.022^{*}$ & -0.277 & $0.004^{*}$ \\
\hline \multirow[t]{2}{*}{ Garrulax cinereifrons } & 75 & 1.37 & 0.64 & 0.82 & 0.95 & 0.652 & 0.524 & 0.032 & 0.768 \\
\hline & 150 & 0.92 & 0.82 & 0.68 & 0.64 & 0.108 & 0.955 & 0.057 & 0.572 \\
\hline Black-naped Monarch & 0 & 0.55 & 0.36 & 0.50 & 0.27 & 1.074 & 0.364 & -0.133 & 0.176 \\
\hline \multirow[t]{2}{*}{ Hypothymis azurea } & 75 & $0.09^{\mathrm{a}}$ & 0.30 & $0.67^{b}$ & $0.56^{\mathrm{b}}$ & 7.250 & $0.000^{*}$ & 0.477 & $0.000^{*}$ \\
\hline & 150 & 0.15 & 0.36 & 0.29 & 0.00 & 1.477 & 0.226 & 0.087 & 0.399 \\
\hline Brown-breasted Flycatcher & 0 & $0.56^{\mathrm{a}}$ & 0.28 & $0.08^{b}$ & $0.00^{b}$ & 6.120 & $0.001^{*}$ & -0.390 & $0.000^{*}$ \\
\hline \multirow[t]{2}{*}{ Muscicapa muttui } & 75 & 0.24 & 0.38 & 0.36 & 0.25 & 1.022 & 0.387 & 0.068 & 0.510 \\
\hline & 150 & 0.47 & 0.69 & 0.71 & 0.77 & 0.547 & 0.651 & 0.121 & 0.238 \\
\hline Brown-headed Barbet & 0 & 0.56 & 0.36 & 0.18 & 0.54 & 1.210 & 0.311 & -0.092 & 0.346 \\
\hline \multirow[t]{2}{*}{ Psilopogon zeylanicus } & 75 & 0.32 & 0.54 & 0.50 & 0.67 & 0.858 & 0.466 & 0.104 & 0.105 \\
\hline & 150 & 0.43 & 0.48 & 0.64 & 0.72 & 1.374 & 0.255 & 0.184 & 0.065 \\
\hline Greater Flameback & 0 & $0.78^{\mathrm{a}}$ & 0.55 & 0.36 & $0.17^{b}$ & 2.890 & $0.039^{*}$ & -0.280 & $0.004^{*}$ \\
\hline \multirow[t]{2}{*}{ Chrysocolaptes guttacristatus } & 75 & 0.24 & 0.41 & 0.28 & 0.20 & 0.872 & 0.460 & 0.041 & 0.690 \\
\hline & 150 & 0.28 & 0.52 & 0.33 & 0.78 & 1.933 & 0.129 & 0.182 & 0.068 \\
\hline Dark-fronted Babbler & 0 & $2.63^{\mathrm{a}}$ & $1.96^{\mathrm{a}}$ & $0.41^{b}$ & $0.17^{b}$ & 5.045 & $0.003^{*}$ & -0.352 & $0.000^{*}$ \\
\hline \multirow[t]{2}{*}{ Rhopocichla atriceps } & 75 & 0.21 & 0.36 & 0.73 & 0.63 & 2.011 & 0.117 & 0.231 & $0.023^{*}$ \\
\hline & 150 & 0.38 & 0.41 & 0.41 & 0.36 & 0.009 & 0.999 & -0.001 & 0.993 \\
\hline Layard's Parakeet & 0 & 0.47 & 0.82 & 0.93 & 0.45 & 1.579 & 0.199 & 0.087 & 0.379 \\
\hline \multirow[t]{2}{*}{ Psittacula calthrapae } & 75 & 0.49 & 0.68 & 0.73 & 0.77 & 0.403 & 0.751 & 0.105 & 0.304 \\
\hline & 150 & 0.63 & 0.79 & 0.82 & 0.89 & 0.301 & 0.825 & 0.092 & 0.367 \\
\hline Malabar Trogon & 0 & $0.96^{\mathrm{a}}$ & 0.76 & 0.36 & $0.23^{b}$ & 4.057 & $0.009^{*}$ & -0.322 & $0.001^{*}$ \\
\hline \multirow[t]{2}{*}{ Harpactes fasciatus } & 75 & $0.21^{\mathrm{a}}$ & 0.38 & 0.38 & $0.89^{b}$ & 2.883 & $0.040^{*}$ & 0.254 & $0.011^{*}$ \\
\hline & 150 & 0.28 & 0.46 & 0.37 & 0.33 & 0.502 & 0.682 & 0.052 & 0.613 \\
\hline Orange-billed Babbler & 0 & $7.39^{\mathrm{a}}$ & $6.75^{\mathrm{a}}$ & $1.63^{b}$ & $0.73^{b}$ & 2.776 & $0.045^{*}$ & -0.254 & $0.008^{*}$ \\
\hline \multirow[t]{2}{*}{ Turdoides rufescens } & 75 & 1.69 & 1.46 & 2.51 & 2.71 & 0.341 & 0.795 & 0.079 & 0.444 \\
\hline & 150 & 1.88 & 1.32 & 1.94 & 1.44 & 0.131 & 0.941 & -0.031 & 0.765 \\
\hline Red-faced Malkoha & 0 & 0.45 & 0.26 & 0.27 & 0.09 & 2.333 & 0.078 & -0.237 & $0.013^{*}$ \\
\hline \multirow[t]{2}{*}{ Phaenicophaeus pyrrhocephalus } & 75 & 0.13 & 0.14 & 0.13 & 0.28 & 0.406 & 0.749 & 0.081 & 0.432 \\
\hline & 150 & 0.16 & 0.22 & 0.31 & 0.25 & 0.553 & 0.648 & 0.111 & 0.271 \\
\hline Scarlet Minivet & 0 & 1.35 & 0.93 & 0.51 & 0.45 & 1.492 & 0.221 & -0.201 & $0.041^{*}$ \\
\hline \multirow[t]{2}{*}{ Pericrocotus flammeus } & 75 & 0.52 & 0.36 & 0.71 & 0.33 & 0.256 & 0.857 & 0.008 & 0.938 \\
\hline & 150 & 0.54 & 0.79 & 0.28 & 0.61 & 0.498 & 0.685 & -0.015 & 0.881 \\
\hline Spot-Winged Thrush & 0 & $1.47^{\mathrm{a}}$ & $0.32^{b}$ & $0.08^{b}$ & $0.07^{b}$ & 7.252 & $0.000^{*}$ & -0.379 & $0.000^{*}$ \\
\hline \multirow[t]{2}{*}{ Zoothera spiloptera } & 75 & 0.21 & 0.41 & 0.64 & 0.71 & 1.252 & 0.285 & 0.188 & 0.059 \\
\hline & 150 & 0.23 & 0.43 & 0.51 & 0.45 & 0.491 & 0.659 & 0.108 & 0.292 \\
\hline Sri Lanka Blue Magpie & 0 & $0.49^{\mathrm{a}}$ & $1.71^{b}$ & $1.64^{b}$ & $0.29^{\mathrm{a}}$ & 9.254 & $0.000^{*}$ & 0.142 & 0.143 \\
\hline \multirow[t]{2}{*}{ Urocissa ornata } & 75 & 0.10 & 0.21 & 0.14 & 0.00 & 0.844 & 0.473 & 0.044 & 0.673 \\
\hline & 150 & 0.17 & 0.43 & 0.14 & 0.67 & 1.864 & 0.142 & 0.153 & 0.129 \\
\hline Sri Lanka Crested Drongo & 0 & 0.84 & 0.55 & 0.92 & 0,17 & 1.926 & 0.130 & -0.159 & 0.099 \\
\hline \multirow[t]{2}{*}{ Dicrurus lophorhinus } & 75 & 0.12 & 0.32 & 0.21 & 0.67 & 1.567 & 0.203 & 0.169 & 0.097 \\
\hline & 150 & 0.22 & 0.46 & 0.44 & 0.67 & 1.087 & 0.358 & 0.169 & 0.091 \\
\hline Sri Lanka Jungle fowl & 0 & 1.01 & 1.56 & 1.23 & 0.56 & 1.796 & 0.153 & -0.031 & 0.749 \\
\hline
\end{tabular}


Table 5 continued

\begin{tabular}{|c|c|c|c|c|c|c|c|c|c|}
\hline \multirow[t]{2}{*}{ Species } & \multirow[t]{2}{*}{$\begin{array}{l}\text { Distance from } \\
\text { trail }(\mathrm{m})\end{array}$} & \multicolumn{4}{|c|}{ Mean number of birds } & \multicolumn{2}{|c|}{ One-way ANOVA } & \multicolumn{2}{|c|}{$\begin{array}{l}\text { Pearson's correla- } \\
\text { tion }\end{array}$} \\
\hline & & NRD & LRD & MRD & HRD & $F$ & $p$ & $r$ & $p$ \\
\hline \multirow[t]{2}{*}{ Gallus lafayetti } & 75 & 0.13 & 0.14 & 0.21 & 0.33 & 0.364 & 0.779 & 0.094 & 0.361 \\
\hline & 150 & 0.12 & 0.10 & 0.07 & 0.00 & 0.153 & 0.928 & -0.070 & 0.521 \\
\hline Sri Lanka Myna & 0 & 0.57 & 0.54 & 0.58 & 0.31 & 0.341 & 0.795 & -0.073 & 0.461 \\
\hline \multirow[t]{2}{*}{ Gracula ptilogenys } & 75 & 0.31 & 0.28 & 0.25 & 0.21 & 0.109 & 0.955 & -0.059 & 0.569 \\
\hline & 150 & 0.29 & 0.23 & 0.07 & 0.22 & 0.651 & 0.584 & -0.105 & 0.305 \\
\hline Sri Lanka Scimitar Babbler & 0 & $1.51^{\mathrm{a}}$ & $0.59^{b}$ & $0.17^{\mathrm{b}}$ & $0.00^{\mathrm{b}}$ & 6.802 & $0.000^{*}$ & -0.393 & $0.000^{*}$ \\
\hline \multirow[t]{2}{*}{ Pomatorhinus melanurus } & 75 & $0.33^{\mathrm{a}}$ & $0.91^{b}$ & $1.14^{\mathrm{b}}$ & $1.17^{b}$ & 4.123 & 0.009 & 0.314 & $0.002^{*}$ \\
\hline & 150 & 0.25 & 0.36 & 0.61 & 0.35 & 0.672 & 0.571 & 0.089 & 0.376 \\
\hline Tickell's Blue Flycatcher & 0 & 0.64 & 0.59 & 0.38 & 0.19 & 1.978 & 0.122 & -0.229 & $0.021^{*}$ \\
\hline \multirow[t]{2}{*}{ Cyornis tickelliae } & 75 & 0.55 & 0.43 & 0.59 & 0.61 & 0.274 & 0.844 & 0.033 & 0.748 \\
\hline & 150 & 0.42 & 0.52 & 0.51 & 0.9 & 1.555 & 0.205 & 0.187 & 0.062 \\
\hline Yellow-browed Bulbul & 0 & $2.02^{\mathrm{a}}$ & $1.78^{\mathrm{a}}$ & 1.36 & $0.73^{b}$ & 2.752 & $0.047^{*}$ & -0.272 & $0.006^{*}$ \\
\hline \multirow[t]{2}{*}{ Iole indica } & 75 & 0.82 & 1.16 & 0.96 & 1.14 & 0.267 & 0.849 & 0.057 & 0.565 \\
\hline & 150 & 0.85 & 0.74 & 0.93 & 0.90 & 0.087 & 0.967 & 0.001 & 0.990 \\
\hline
\end{tabular}

Items with different superscripts (lowercase letters) indicate significant difference of means according to Games-Howell post hoc tests. Items without superscripts do not significantly differ from those with superscripts

* Statistical significance at $a=0.05$ level

Received: 13 May 2016 Accepted: 9 September 2016

Published online: 22 September 2016

\section{References}

Baudains TP, Lloyd P. Habituation and habitat changes can moderate the impacts of human disturbance on shorebird breeding performance. Anim Conserv. 2007;10:400-7.

Bautista LM, García JT, Calmaestra RG, Palacín C, Martín CA, Morales MB, Bonal $\mathrm{R}$, Viñuela J. Effect of weekend road traffic on the use of space by raptors. Conserv Biol. 2004;18:726-32.

BirdLife International. IUCN Red List for birds. 2015. http://www.birdlife.org. Blumstein DT, Anthony LL, Harcourt R, Ross G. Testing a key assumption of wildlife buffer zones: is flight initiation distance a species-specific trait? Biol Conserv. 2003;110:97-100.

Bolduc F, Guillemette M. Human disturbance and nesting success of Common Eiders: interaction between visitors and gulls. Biol Conserv. 2003; 110:77-83.

Borgmann KL. A review of human disturbance impacts on waterbirds. 2010. http://www.audubon.org/sites/default/files/documents/humandisturbanceimpactsreportfinal.pdf.

Buckley R. Impacts of ecotourism on birds. In: Buckley R, editor. Environmental impacts of ecotourism. Cambridge: CAB International; 2004. p. 187-209.

Burger J, Jeitner C, Clark K, Niles LJ. The effect of human activities on migrant shorebirds: successful adaptive management. Environ Conserv. 2004;31:283-8.

Cardoni DA, Favero M, Isacch JP. Recreational activities affecting the habitat use by birds in Pampa's wetlands, Argentina: implications for waterbird conservation. Biol Conserv. 2008;141:797-806.

Chazdon RL, Peres CA, Dent D, Sheil D, Lugo AE, Lamb D, Stork NE, Miller SE. The potential for species conservation in tropical secondary forests. Conserv Biol. 2009:23:1406-17.

Fernández-Juricic E, Jimenez MD, Lucas E. Alert distance as an alternative measure of bird tolerance to human disturbance: implications for park design. Environ Conserv. 2001a;28:263-9.
Fernández-Juricic E, Jimenez MD, Lucas E. Bird tolerance to human disturbance in urban parks of Madrid (Spain): management implications. In: Marzluff JM, Bowman R, Donnelly R, editors. Avian ecology and conservation in an urbanizing world. Springer: US; 2001 b. p. 259-73.

Fernández-Juricic E, Tellería JL. Effects of human disturbance on spatial and temporal feeding patterns of Blackbird Turdus merula in urban parks in Madrid, Spain. Bird Study. 2000;47:13-21.

Fernández-Juricic E, Vaca R, Schroeder N. Spatial and temporal responses of forest birds to human approaches in a protected area and implications for two management strategies. Biol Conserv. 2004;117:407-16

Fernández-Juricic E. Local and regional effects of pedestrians on forest birds in a fragmented landscape. Condor. 2000;102:247-55.

Finney SK, Pearce-Higgins JW, Yalden DW. The effect of recreational disturbance on an upland breeding bird, the golden plover Pluvialis apricaria. Biol Conserv. 2005;121:53-63.

Gibson L, Lee TM, Koh LP, Brook BW, Gardner TA, Barlow J, Peres CA, Bradshaw CJA, Laurance WF, Lovejoy TE, Sodhi NS. Primary forests are irreplaceable for sustaining tropical biodiversity. Nature. 2011;478:378-81.

Gill JA. Approaches to measuring the effects of human disturbance on birds. Ibis. 2007:149:9-14.

González-Oreja JA, De La Fuente-Díaz AA, Hernández-Santín L, BonacheRegidor C, Buzo-Franco D. Can human disturbance promote nestedness? Songbirds and noise in urban parks as a case study. Landscape Urban Plan. 2012;31:9-18.

Goodale E, Kotagama SW. Testing the roles of species in mixed-species bird flocks of a Sri Lankan rain forest. J Trop Ecol. 2005;21:669-76.

Gunatilleke CVS, Gunatilleke IAUN. The floristic composition of Sinharaja: a rain forest in Sri Lanka with special reference to endemics and Dipterocarps. Malaysian Forester. 1981;44:386-96.

Harrison J, Worfolk T. A field guide to the birds of Sri Lanka. USA: Oxford University Press; 2011.

Henry GM. A guide to the birds of Sri Lanka. USA: Oxford University Press; 1998

Holm TE, Laursen K. Experimental disturbance by walkers affects behaviour and territory density of nesting Black-tailed Godwit Limosa limosa. Ibis. 2009:151:77-87.

Klein ML, Humphrey SR, Percival HF. Effects of ecotourism on distribution of waterbirds in a wildlife refuge. Conserv Biol. 1995;9:1454-65. 
Kotagama SW, Goodale E. The composition and spatial organization of mixedspecies flocks in a Sri Lankan rainforest. Forktail. 2004;20:63-70.

Kotagama SW. Birds of Sinharaja. Colombo: Field Ornithology Group of Sri Lanka; 2006.

Mallord JW, Dolman PM, Brown AF, Sutherland WJ. Linking recreational disturbance to population size in a ground-nesting passerine. J Appl Ecol. 2007:44:185-95.

Marcum HA. The effects of human disturbance on birds in Bastrop State Park. Doctoral dissertation. Texas A\&M University, USA; 2005.

McGowan CP, Simons TR. Effects of human recreation on the incubation behaviour of American Oystercatchers. Wilson J Ornithol. 2006;118:485-93.

Pease ML, Rose RK, Butler MJ. Effects of human disturbances on the behavior of wintering ducks. Wildl Soc Bull. 2005;33:103-12.

Perera P, Vlosky RP, Wahala SB. Motivational and behavioral profiling of visitors to forest-based recreational destinations in Sri Lanka. Asia Pac J Tour Res. 2012;17:451-67.

Peters KA, Otis DL. Wading bird response to recreational boat traffic: does flushing translate into avoidance? Wildl Soc Bull. 2006;34:1383-91.

Rasmussen PC, Anderton JC. Birds of south Asia: the Ripley guide. Washington DC: Smithsonian Institution, Lynx Edicions; 2012.

Remacha C, Pérez-Tris J, Delgado JA. Reducing visitors' group size increases the number of birds during educational activities: implications for management of nature-based recreation. J Environ Manag. 2011;92:1564-8.

Rodgers JA, Schwikert ST. Buffer-zone distances to protect foraging and loafing waterbirds from disturbance by personal watercraft and outboardpowered boats. Conserv Biol. 2002;16:216-24.

Ruddock M, Whitfield DP. A review of disturbance distances in selected bird species. Conducted by Natural Research Ltd. Inverness. UK: Scottish Natural Heritage; 2007.

Schlacher TA, Nielsen T, Weston MA. Human recreation alters behaviour profiles of non-breeding birds on open-coast sandy shores. Estuar Coast Shelf Sci. 2013;118:31-42.

Shermila WG, Wikramasinghe $S$. Composition of mix species foraging flocks of birds in riverstan of Montane Region, Sri Lanka. J Trop Forest Environ. 2013;3:55-63.
Siriwardhane AMS. Microhabitat selection by the Ashy-headed Laughingthrush Garruluax cinefrons (Sylviidae) in unlogged and regenerating selectively logged forest tracts in the Sinharaja World Heritage Site, Sri Lanka. MSc Thesis, University of Colombo, Sri Lanka; 2007.

Smith-Castro JR, Rodewald AD. Behavioral responses of nesting birds to human disturbance along recreational trails. J Field Ornithol. 2010;81:130-8.

Sri Lanka Forest Department. Annual visitor records. Sri Lanka: Forest Department; 2014.

Stankowich T, Blumstein DT. Fear in animals: a meta-analysis and review of risk assessment. Proc R Soc Lond B Biol. 2005;272:2627-34.

Steven R, Pickering C, Castley JG. A review of the impacts of nature based recreation on birds. J Environ Manag. 2011;92:2287-94.

Stolen ED. The effects of vehicle passage on foraging behavior of wading birds. Waterbirds. 2003;26:429-36.

Suntikul W, Butler R, Airey D. Implications of political change on national park operations: doi moi and tourism to Vietnam's national parks. J Ecotour. 2010;9:201-18

Sutherland WJ. Ecological census techniques: a handbook. Cambridge: Cambridge University Press; 2006.

Verhulst S, Oosterbeek K, Ens BJ. Experimental evidence for effects of human disturbance on foraging and parental care in Oystercatchers. Biol Conserv. 2001;101:375-80.

Wang Y, Ding P, Chen S, Zheng G. Nestedness of bird assemblages on urban woodlots: implications for conservation. Landscape Urban Plan. 2013;111:59-67.

Warakagoda D, Inskipp C, Inskipp T, Grimmett R. Birds of Sri Lanka. London: Christopher Helm; 2012.

Weerakoon K. Territory identification, behavioral and feeding observation of Spot-Winged Thrush (Zoothera spiloptera) in two wet zone forest patches of Sri Lanka. M.Phil. Thesis, University of Colombo, Sri Lanka; 2007.

Whitfield DP, Rae R. Human disturbance of breeding Wood Sandpipers Tringa glareola: implications for "alert distances" in prescribing protective buffer zones. Ornis Fenn. 2014;91:57.

\section{Submit your next manuscript to BioMed Central and we will help you at every step:}

- We accept pre-submission inquiries

- Our selector tool helps you to find the most relevant journal

- We provide round the clock customer support

- Convenient online submission

- Thorough peer review

- Inclusion in PubMed and all major indexing services

- Maximum visibility for your research

Submit your manuscript at www.biomedcentral.com/submit
() BioMed Central 